\title{
Photosynthetic Characteristics of Hybrid and Conventional Rice Plants as a Function of Plant Competition ${ }^{1}$
}

\author{
Características Fotossintéticas de Plantas de Arroz Híbridas e Convencionais em Função da \\ Intensidade de Competição
}

\author{
CONCENÇO, G. ${ }^{2}$, ASPIAZÚ, I. ${ }^{3}$, GALON, L. ${ }^{4}$, FERREIRA, E.A. ${ }^{5}$, FREITAS, M.A.M. ${ }^{6}$, \\ FIALHO, C.M.T. ${ }^{6}$, SCHWANKE, A.M.L. ${ }^{7}$, FERREIRA, F.A. ${ }^{6}$ and SILVA, A.A. ${ }^{6}$
}

\begin{abstract}
The objective of this work was to evaluate the characteristics related to the photosynthetic ability of hybrid and inbred rice varieties, as a way to assess which of the two presented higher potential to stand out under conditions of competition. The trial was set in a greenhouse in completely randomized block design and $2 \times 6$ factorial scheme with four replications. Factor A consisted of rice varieties (hybrid or inbred) and factor B by competition levels. Treatments consisted in maintaining one plant of either BRS Pelota (inbred) or Inov (hybrid) variety at the center of the plot, under competition with $0,1,2,3,4$ or 5 plants of the variety BRS Pelota at the periphery of the experimental unit, according to the treatment. Fifty days after emergence (DAE), sub-stomatal $\mathrm{CO}_{2}$ concentration $\left(\mathrm{Ci}-\mathrm{mmol} \mathrm{mol}^{-1}\right)$, photosynthetic rate $\left(\mathrm{A}-\mathrm{mmol} \mathrm{m} \mathrm{m}^{-2} \mathrm{~s}^{-1}\right)$ and $\mathrm{CO}_{2}$ consumed $\left(\mathrm{DC}-\mathrm{mmol} \mathrm{mol} \mathrm{l}^{-1}\right)$ were quantified, as well as shoot dry mass (SDM). Hybrid plants present higher photosynthesis capacity than inbred plants, when competing with up to 3 times its own density. When under the same competitive intensity, hybrid plants surpass the inbred. However, it should be emphasized that, when in farm condition, the lower competitive capacity with weeds often attributed to the hybrid varieties, probably is due to their lower planting density, but if weed competition is kept at low levels, hybrid rice plants may perform in the same way or usually better than inbred plants.
\end{abstract}

Keywords: competitive ability, plant physiology, Oryza sativa.

\begin{abstract}
RESUMO-Objetivou-se com este estudo avaliar caracteristicas relacionadas a capacidade fotossintética de variedades de arroz híbridas e convencionais, de forma a quantificar seu potencial de competição. O experimento foi instalado em casa de vegetação em delineamento experimental de blocos casualizados e esquema fatorial $2 \times 6$, com quatro repetições. O fator A consistiu de variedades de arroz (convencional e híbrida) e o fator $B$ de niveis de competição. Os tratamentos consistiram em manter uma planta da variedade BRS Pelota (convencional) ou Inov (híbrida) no centro da unidade experimental, sob competição com 0, 1, 2, 3, 4 ou 5 plantas da variedade BRS Pelota na periferia, de acordo com o tratamento. Cinquenta dias após a emergência (DAE), concentração de $\mathrm{CO}_{2}$ subestomática (Cimmol mol-1), taxa fotossintética $\left(A-m m o l ~ m^{2} \mathrm{~s}^{1}\right)$ e $\mathrm{CO}_{2}$ consumido durante a avaliação (DC-mmol mol-1) foram quantificados, bem como a massa seca da parte aérea das plantas (SDM). Plantas híbridas apresentaram maior capacidade fotossintética que as convencionais, quando sob competição com até três vezes sua própria densidade. Sob mesma intensidade de competição, plantas híbridas são superiores as convencionais. No entanto, deve-se enfatizar que em condições de campo a menor habilidade competitiva com plantas daninhas normalmente atribuida as variedades hibridas, provavelmente se deve a sua menor densidade de semeadura, mas se a densidade de plantas daninhas é mantida em niveis adequados plantas híbridas de arroz podem apresentar desempenho similar ou normalmente superior ao de plantas convencionais.
\end{abstract}

Palavras-chave: habilidade competitiva, fisiologia vegetal, Oryza sativa.

1 Recebido para publicação em 14.12.2010 e aprovado em 17.5.2011.

2 International Agronomist, Valmont Industries - Irrigation Division. 7002 North 288th Street, P.O. Box 358, Valley, Nebraska 68064 USA, <germani.concenco@valmont.com>; ${ }^{3}$ Agronomist, D. Sc., Professor, Universidade Estadual de Montes Claros, Montes Claros-MG, <aspiazu@gmail.com>; ${ }^{4}$ Agronomist, D.Sc, Professor, Universidade Federal do Pampa - Unipampa, Itaqui-RS, <galonleandro@ig.com.br>; ${ }^{5}$ Agronomist, D.Sc., Post-Doc, Universidade Federal dos Vales do Jequitinhonha e Mucuri - UFVJM, Diamantina-MG, Brazil, <evanderalves@yahoo.com.br>; ${ }^{6}$ Agronomist, D.Sc., Professor, Universidade Federal de Viçosa - UFV, Viçosa-MG, <aasilva@ufv.br>; ${ }^{7}$ Agronomist, M.Sc., researcher at Ricetec Corporation, Brazil, <aschwanke@ricetec.com.br>.

Planta Daninha, Viçosa-MG, v. 29, n. 4, p. 803-809, 2011 


\section{INTRODUCTION}

Rice is grown in more than 3 million hectares in Brazil, and this grain is a staple food in Brazilian diets (Fleck et al., 2008). Rice growers at the Southern region of the Country are highly specialized, and crop yields can be as high as 12 metric tons per hectare, in some commercial fields. On the other hand, in the last cropping season (2009/2010) yield averages were around 7.0 metric tons per hectare at that region. Efficient weed control is among the factors that cause relevant damage to this crop, limiting yields as well as the post-harvest grain quality. This is due mainly to the lack of use of alternative weed control methods (cultural, physical, mechanical) as crop rotation and direct seeding, depending mainly on chemicals for efficient weed control. If from one side chemicals are highly efficient in controlling troublesome weeds, on the other hand they can cause problems like crop toxicity and weed resistance to herbicides.

There are some management options which can be adopted to minimize the negative effects of weed interference on the rice crop; among them, use of varieties with faster emergence, vigorous tillering and higher leaf area index can be highlighted. Therefore, crop canopy close faster, contributing to a better use of environmental resources by the crop at the expense of weeds (Agostinetto et al., 2004; Galon et al., 2007; Fleck et al., 2008). The ability of a plant to surpass competition favors yield and the efficient use of environmental resources, particularly regarding physiological characteristics associated with photosynthetic rate and mass accumulation (Vander Zee \& Kennedy, 1983; Melo et al., 2006).

Hybrid vigor is a feature that normally provides to crops greater capacity of using resources and increasing growth rate. For rice, with highly homozygote plants, and very low rates of cross-fertilization. Several researchers reported variable crossing rates in rice of 0.27 to $0.4 \%$ (Reaño \& Pham, 1998), 0.02 to $0.26 \%$ (Noldin et al., 2002) and 0.1\% (Messinger et al., 2001). However, according to these studies, these values found depend on anthesis synchrony, variety, environment and especially the distance between plants involved in the process.
Currently, hybrid vigor is being explored in hybrid rice crop in order to achieve higher yields than those currently provided by traditional homozygote varieties. A plant with higher heterosis usually presents faster and more vigorous growth, developing its canopy first than most weeds, and increasing its competitive ability (Harlan et al., 1973) provoded that they were planted at the same density, or in absence of weed competition (Galon et al., 2007).

Vegetation modifies the light environment in different ways depending on the geometry of the plants, the distribution of biomass, and the spectral properties and orientation of leaves (Barbour et al., 1980). When light profile is changed, several parameters are changed. Shifts at these parameters can be used as a tool to infer about plant communities, mainly in terms of competitive ability. As stated by Radosevich et al. (1997), a given plant species may be more competitive either by capturing more efficiently a given resource or by using this resource more efficiently. In addition, these authors state that light and water are the main two factors prone to competition inside a plant community.

So far, few studies have reported the importance of photosynthetic rate and efficient water use on the competitiveness of rice plants. There are several factors influencing photosynthesis rate directly or indirectly, such as water deficit, heat stress (Loreto \& Bongi, 1989), leaf internal and external gas concentration (Kirschbaum \& Pearcey, 1988) and light composition and intensity (Sharkey \& Raschke, 1981), among others. Whereas the stomatal ability of conduction and gas exchange is deemed to be the main limitation for assimilation of photosynthetic $\mathrm{CO}_{2}$ (Hutmacher \& Krieg, 1983), it is unlikely that gas exchange will limit the photosynthetic rate when in interaction with other factors.

Photosynthetic rate is directly related to the photosynthetically active radiation (composition of light), to the factors of water availability and to gas exchanges (NavesBarbiero et al., 2000). Plants have specific needs for light, predominantly within red and blue bands (Messinger et al., 2006). If the plant does not receive these light lengths in a satisfactory way, it will need to adapt to survive 
(Attridge, 1990). When plants are under competition for light, it also becomes important the red/far-red balancing (Weller et al., 1997), which is modified by shading, affecting directly the photosynthetic efficiency (Da Matta et al., 2001).

The objective of this work was to evaluate the characteristics related to the photosynthetic ability of hybrid and inbred rice varieties, as a way to assess which of the two present higher potential to stand out under conditions of competition.

\section{MATERIAL AND METHODS}

The experiment was set in a greenhouse with automated sprinkler irrigation system, in a completely randomized block design, in a $2 \times 6$ factorial scheme with four replications. Factor A consisted of rice varieties (hybrid or inbred) and factor B by competition levels. Experimental plots consisted of plastic buckets containing $13 \mathrm{~L}$ of soil, previously corrected and fertilized according to soil analysis. Treatments consisted in maintaining one plant of either BRS Pelota (inbred) or Inov (hybrid) variety at the center of the plot, under competition with $0,1,2,3,4$ or 5 plants of the variety BRS Pelota at the periphery of the experimental unit, according to the treatment.

At the center of the plot, three seeds of the variety to be tested were planted, whereas at the periphery of the same plot, six seeds of the variety BRS Pelota were planted. Ten days after emergence (DAE), the number of plants was standardized to one plant of rice at the center of the plot, varying from 0 to 5 the number of plants at the periphery. The experimental units were kept equidistant, so that the surface area available for the development of plants corresponded to the approximate area of the experimental unit.

Fifty DAE, the analyses were carried out at the first fully expanded leaf of the plant located at the center of the plot. It was used an infrared gas analyzer - IRGA, model LCA Pro ${ }^{+}$(Analytical Development Co. Ltd, Hoddesdon) in open greenhouse, allowing free air circulation. Substomatal $\mathrm{CO}_{2}$ concentration $\left(\mathrm{Ci}-\mu \mathrm{mol} \mathrm{mol}^{-1}\right.$ ), photosynthetic rate $\left(\mathrm{A}-\mu \mathrm{mol} \mathrm{m} \mathrm{m}^{-2} \mathbf{s}^{-1}\right)$ and $\mathrm{CO}_{2}$ consumed $\left(\Delta \mathrm{C}-\mu \mathrm{mol} \mathrm{mol}^{-1}\right)$ during the evaluation period were quantified.
All the above-ground (shoot) mass of the central plant were also collected and the material was dried in a stove at $60{ }^{\circ} \mathrm{C}$ to constant weight, and weighed on analytical scale, which returned the shoot dry mass (SDM) variable. Each block was evaluated in one day, from 7:00 to 9:00 a.m. in order to keep homogeneous environmental conditions during evaluation of that set of treatments. In each experimental plot, only the central plant was evaluated; plants at the periphery were used only to impose competition during the development of the central plant, from emergence to plant evaluations (50 DAE).

Data were submitted to analysis of variance by F-test and in case of significance, it was applied the DMRT test in order to evaluate the effect of increasing the plants density, and the Least Significant Difference (LSD) test was used to evaluate differences between the inbred or hybrid rice varieties in each competition intensity. All data were analyzed at $5 \%$ probability.

\section{RESULTS AND DISCUSSION}

Shoot dry mass of both varieties decreased as competition increased (Table 1). Isolated plants (checks) were superior to plants submitted to competition. Similarly, hybrid and inbred varieties did not differ in dry mass accumulation in any of the treatments. It can be inferred that the intra-plant competition between parts of the same rice plant - was relevant in determining mass accumulation, as described for basic and applied studies by Radosevich et al. (1997) and Fleck et al. (2008). It is possible to speculate that hybrid rice plants have favored the growth in height in lieu of mass accumulation in leaves, as a way to stand out to in the competition. This hypothesis was observed by Aspiazu et al. (2008), who reported that barnyard grass (Echinochloa crusgalli), even presenting similar dry mass, may differ widely as to the competitive ability according to the partition of photosynthates, e.g. promoting greater mass accumulation in stems at expense of leaves, as a way to obtain advantage in competition for light when under high intraspecific competition, or when under competition against plants with similar morphophysiological characteristics. 
Table 1 - Shoot dry mass (g per plant) of rice plants, in function of variety and competition intensity in controlled environment, 50 days after emergence

\begin{tabular}{|c|c|c|c|}
\hline \multirow{2}{*}{$\begin{array}{c}\text { SDM } \\
\text { Treatment }\end{array}$} & \multicolumn{2}{|c|}{ Rice variety } & \multirow{2}{*}{ Difference $^{1 /}$} \\
\cline { 2 - 3 } & BRS Pelota & Inov & \\
\hline $1:(0)$ & $36.58 \mathrm{a}^{2 / /}$ & $36.48 \mathrm{a}$ & $0.1^{\mathrm{ns}}$ \\
\hline $1:(1)$ & $13.10 \mathrm{~b}$ & $12.28 \mathrm{~b}$ & $0.82^{\mathrm{ns}}$ \\
\hline $1:(2)$ & $8.76 \mathrm{~b}$ & $6.99 \mathrm{~b}$ & $1.77^{\mathrm{ns}}$ \\
\hline $1:(3)$ & $6.33 \mathrm{~b}$ & $6.47 \mathrm{~b}$ & $-0.14^{\mathrm{ns}}$ \\
\hline $1:(4)$ & $5.84 \mathrm{~b}$ & $5.66 \mathrm{~b}$ & $0.18^{\mathrm{ns}}$ \\
\hline $1:(5)$ & $4.47 \mathrm{~b}$ & $5.17 \mathrm{~b}$ & $-0.7^{\mathrm{ns}}$ \\
\hline
\end{tabular}

ns - non-significant by the LSD; ${ }^{1 /}$ one rice plant in the center of the experimental unit competing with the number of plants within parenthesis; ${ }^{2 /}$ means followed by the same letter, in the column, do not differ by the DMRT test.

Results for consumed $\mathrm{CO}_{2}$ showed to vary widely among treatments. However, in general terms, it can be observed that when competition was higher, there was a decrease trend in $\mathrm{CO}_{2}$ use by rice plants (Table 2). The authors hypothesize that under higher competitive intensity, plants were subjected to higher competition for light, and photosynthetic rate was affected. As a consequence, $\mathrm{CO}_{2}$ use was proportionately smaller. It is also observed that at intermediary competition intensities, $\mathrm{CO}_{2}$ consumed was higher in Inov hybrid variety plants. When under the same competition intensity, this variety presented $\mathrm{CO}_{2}$ use rate $35 \%$ higher than plants of the non-hybrid variety. This superiority was observed when the central hybrid plant was under competition with 1,2 or 3 plants of BRS Pelota. For treatments 1:(4) and $1:(5)$, the hybrid plant started being affected by competition at the same level as the inbred plant (Table 2).

Internal $\mathrm{CO}_{2}$ concentration in the leaf was reduced for both varieties as competition increased (Table 3). However, inbred plants increased $\mathrm{CO}_{2}$ concentration in the leaf at lower competition intensities than hybrid plants. For BRS Pelota plants, $\mathrm{CO}_{2}$ concentration in intercellular spaces was

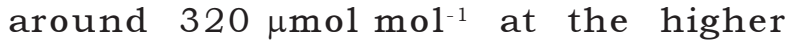
competition intensities whereas for Inov this concentration was close to $305 \mu \mathrm{mol} \mathrm{mol}^{-1}$. At smaller densities, hybrid plants presented $\mathrm{CO}_{2}$ concentrations in leaves always lower than that observed for inbred plants, under the same competition level (Table 3). The internal $\mathrm{CO}_{2}$ concentration in leaves is considered a physiological variable influenced by environmental factors as water availability, light and energy, among others (Ometto et al., 2003). Higher $\mathrm{CO}_{2}$ concentration inside leaves of BRS Pelota under competition indicates high interference by other plants and, probably, smaller photosynthetic rate for this variety. In simple terms, inbred plants were more affected by competition than hybrid plants because they were able to process less $\mathrm{CO}_{2}$ under the same competition level.

Until recently, the most accepted theory was that light affected indirectly stomatal opening through its effect on $\mathrm{CO}_{2}$ assimilation (Nishio et al., 1994). However, Sharkey \& Raschke, (1981) and Floss (2008) reported that stomatal opening is less dependent on the $\mathrm{CO}_{2}$ concentration in the leaf, responding directly to light. Thus, under competition and shading, light balance participates in stomatal opening and gas balance between the internal part of the leaf and the external environment (Loreto \& Bongi, 1989). In studies with sunflower plants under stress, $\mathrm{CO}_{2}$ concentration inside the leaf increased as photosynthesis rate reduced (Corniani et al., 2006), corroborating with the results obtained in this work. When the agent causing the stress was removed, the plant recovered its photosynthetic capacity and the $\mathrm{CO}_{2}$ concentration was normalized.

The photosynthetic rate of both varieties was affected as competition increased.

Table 2 - $\mathrm{CO}_{2}$ consumed $\left(\mu \mathrm{mol} \mathrm{mol}{ }^{-1}\right)$ by rice plants, in function of variety and competition intensity in controlled environment, 50 days after emergence

\begin{tabular}{|c|c|c|c|}
\hline \multirow{2}{*}{$\begin{array}{c}|c| \\
\text { Treatment }\end{array}$} & \multicolumn{2}{|c|}{ Rice variety } & \multirow{2}{*}{ Difference ${ }^{1 /}$} \\
\cline { 2 - 3 } & BRS Pelota & Inov & \\
\hline $1:(0)$ & $48.5 \mathrm{a}^{\underline{2}}$ & $42.8 \mathrm{bc}$ & $5.7^{\mathrm{ns}}$ \\
\hline $1:(1)$ & $36.3 \mathrm{bc}$ & $56.3 \mathrm{a}$ & $-20.0^{*}$ \\
\hline $1:(2)$ & $37.0 \mathrm{~b}$ & $58.0 \mathrm{a}$ & $-21.0^{*}$ \\
\hline $1:(3)$ & $33.0 \mathrm{c}$ & $46.3 \mathrm{~b}$ & $-13.3^{*}$ \\
\hline $1:(4)$ & $43.5 \mathrm{ab}$ & $38.8 \mathrm{bc}$ & $4.7^{\mathrm{ns}}$ \\
\hline $1:(5)$ & $32.8 \mathrm{c}$ & $35.8 \mathrm{c}$ & $-3.0^{\mathrm{ns}}$ \\
\hline
\end{tabular}

ns - non-significant and significant, respectively, by the LSD; ${ }^{1 /}$ one rice plant in the center of the experimental unit competing with the number of plants within parenthesis; ${ }^{2} /$ means followed by the same letter, in the column, do not differ by the DMRT test. 
Table 3 - $\mathrm{CO}_{2}$ concentration within the leaf $\left(\mu \mathrm{mol} \mathrm{mol}{ }^{-1}\right)$ of rice plants, in function of variety and competition intensity in controlled environment, 50 days after emergence

\begin{tabular}{|c|c|c|c|}
\hline \multirow{2}{*}{$\begin{array}{c}\mathrm{Ci} \\
\text { Treatment }\end{array}$} & \multicolumn{2}{|c|}{ Rice variety } & \multirow{2}{*}{ Difference $^{\mathrm{1}}$} \\
\cline { 2 - 3 } & BRS Pelota & Inov & \\
\hline $1:(0)$ & $267 \mathrm{~b}^{-/}$ & $209 \mathrm{c}$ & $58^{*}$ \\
\hline $1:(1)$ & $298 \mathrm{ab}$ & $262 \mathrm{~b}$ & $36^{*}$ \\
\hline $1:(2)$ & $321 \mathrm{a}$ & $280 \mathrm{ab}$ & $41^{*}$ \\
\hline $1:(3)$ & $324 \mathrm{a}$ & $292 \mathrm{ab}$ & $32^{*}$ \\
\hline $1:(4)$ & $315 \mathrm{a}$ & $302 \mathrm{a}$ & $13^{\mathrm{ns}}$ \\
\hline $1:(5)$ & $316 \mathrm{a}$ & $309 \mathrm{a}$ & $7^{\mathrm{ns}}$ \\
\hline
\end{tabular}

ns - non-significant and significant, respectively, by the LSD; ${ }^{1 /}$ one rice plant in the center of the experimental unit competing with the number of plants between parenthesis; $\underline{2}$ means followed by the same letter, in the column, do not differ by the DMRT test.

Varieties did not differ from the check free of competition until the treatment 1:(2), i.e., one plant at the center of the plot under competition with two plants of the inbred variety (Table 4). From this point on, hybrid plants were more affected by the competition than inbred plants. In the absence of competition, photosynthetic rate of hybrid plants was approximately 34\% higher than that observed in plants of the BRS Pelota variety. Furthermore, plants of the Inov variety were superior to the inbred, under the same competition intensity, when competing with up to 3 plants of the opposite variety. When the variables associated with photosynthesis are considered, it is observed that while the photosynthesis (Table 4) decreased with the increase in competition between plants, $\mathrm{CO}_{2}$ concentration inside the leaf increased proportionately (Table 3). Similarly, the gradient between the amount of $\mathrm{CO}_{2}$ in the air outside and the amount of $\mathrm{CO}_{2}$ inside the leaf changed inasmuch as the plant did not incorporate $\mathrm{CO}_{2}$ by photosynthesis (Table 2).

Even with higher photosynthetic rates at lower competition intensities, hybrid plants were not superior to inbreds on the accumulation of dry mass, under the same competition levels (Table 1). The most plausible explanations are pointed as follows: (1) in addition to greater photosynthesis, hybrid plants present higher respiratory rates than inbred plants. Thus, much of the amount of $\mathrm{CO}_{2}$ incorporated is consumed by the respiratory process to generate energy, which may be being converted into heat. (2) Due to the increased photosynthesis, plants of the hybrid variety reduce very fast the amount of $\mathrm{CO}_{2}$ available inside and close to the canopy, and thus their photosynthesis rate is limited by the resulting lower $\mathrm{CO}_{2}$ concentration in the air layer next to the leaves. (3) Photorespiratory rate in hybrid plants may be higher and help reducing $\mathrm{CO}_{2}$ use efficiency. Although this is possible, it was not measured and this is unlikely to be the cause, otherwise such high reductions in the internal $\mathrm{CO}_{2}$ in the leaf of hybrid plants would not be observed, because great part of the $\mathrm{CO}_{2}$ used by photosynthesis would return to the air inside leaf through photorespiration and again be available to be reused.

Some field studies compared the competitive potential of hybrid and inbred varieties for their ability to compete with the main weeds of rice crop, and concluded that at the respectively recommended seeding rates, the hybrid variety Avaxi was less competitive than the others for some features (Galon et al., 2007). Similarly, for this variety, the economic threshold level (ETL) was lower than that observed for the non-hybrid varieties (Galon et al., 2007). It should be noted, however, that the seed density of these trials was $125 \mathrm{~kg} \mathrm{ha}^{-1}$ for inbred varieties and $50 \mathrm{~kg} \mathrm{ha}^{-1}$ for the hybrid variety Avaxi, according to recommendation of some works (Sosbai, 2007). As stressed by the authors, the

Table 4 - Photosynthetic rate $\left(\mu \mathrm{mol} \mathrm{m} \mathrm{m}^{-2} \mathrm{~s}^{-1}\right)$ of rice plants, in function of variety and competition intensity in controlled environment, 50 days after emergence

\begin{tabular}{|c|c|c|c|}
\hline A & \multicolumn{2}{|c|}{ Rice variety } & \multirow{2}{*}{ Difference ${ }^{1 /}$} \\
\hline Treatment & BRS Pelota & Inov & \\
\hline $1:(0)$ & $15.37 \mathrm{a}^{\frac{2}{}}{ }^{\prime}$ & $20.65 \mathrm{a}$ & $-5.28^{*}$ \\
\hline $1:(1)$ & $11.52 \mathrm{ab}$ & $17.06 \mathrm{ab}$ & $-5.54^{*}$ \\
\hline $1:(2)$ & $11.82 \mathrm{ab}$ & $18.52 \mathrm{ab}$ & $-6.7^{*}$ \\
\hline $1:(3)$ & $10.55 \mathrm{~b}$ & $14.73 \mathrm{bc}$ & $-4.18^{*}$ \\
\hline $1:(4)$ & $11.16 \mathrm{~b}$ & $12.37 \mathrm{c}$ & $-1.21^{\mathrm{ns}}$ \\
\hline $1:(5)$ & $8.87 \mathrm{~b}$ & $12.44 \mathrm{c}$ & $-3.57^{\mathrm{ns}}$ \\
\hline
\end{tabular}

ns - non-significant and significant, respectively, by the LSD test; ${ }^{1 /}$ one rice plant in the center of the experimental unit competing with the number of plants within parenthesis; ${ }^{2 /}$ means followed by the same letter, in the column, do not differ by the DMRT test. 
objective was to simulate the situation that rice growers meet in the field and what would happen when these varieties are under competition against the most aggressive weed of rice fields, which is Echinochloa spp. But, in this case the author agree that considering proper weed control, hybrid plants would grow faster than inbred plants, but also remarks the great differences in seeding rates should be considered for competitive aggressiveness under field conditions.

According to the data from in this work, it can be inferred that when under the same competition levels or planting densities, plants of the hybrid variety are more competitive than inbred plants. Also, hybrid plants were superior as to the photosynthesis rate when competing with up to 3 non-hybrid plants. The same was observed on the $\mathrm{CO}_{2}$ concentration inside the leaf.

It is possible to infer that Inov plants present higher photosynthesis capacity than BRS Pelota, when competing with up to 3 times its own density, when considering all other resources (irrigation, fertilization) are properly supplied and external interferences (pests and diseases) are not an issue. When under the same competitive intensity, hybrid plants surpass the inbred. However, it should be emphasized that, at farm conditions, the lower competitive capacity with weeds often attributed to the hybrid varieties, is probably due to their lower planting density, but if weed competition is kept at low levels, hybrid rice plants may perform in the same way or better than inbred plants.

\section{LITERATURE CITED}

AGOSTINETTO, D. et al. Perdas de rendimento de grãos na cultura de arroz irrigado em função da população de plantas e da época relativa de emergência de arroz-vermelho ou de seu genótipo simulador de infestação de arrozvermelho. Planta Daninha, v. 22, n. 2, p. 175-183, 2004.

ASPIAZÚ, I. et al. Relação colmos/folhas de biótipos de capim-arroz em condição de competição. R. Trópica, v. 1, n. 2, p. 22-30, 2008

ATTRIDGE, T. H. The natural light environment. In: ATTRIDGE, T. H. (Ed.). Light and plant responses. London: Edward Arnold, 1990. p. 1-5.

Planta Daninha, Viçosa-MG, v. 29, n. 4, p. 803-809, 2011
BARBOUR, M. G.; BURK, J. H.; PITTS, W. D. Terrestrial plant ecology. Menlo Park: Benjamin/Cummings Publishing Company, 1980. 604 p.

CORNIANI, N. et al. Determinação das trocas gasosas e de potencial hídrico através do uso de sistemas portáteis na avaliação do estresse. In: SIMPÓSIO INTERNACIONAL DE INICIAÇÃO CIENTÍFICA DA UNIVERSIDADE DE SÃO PAULO, 14., 2006, Piracicaba. Anais... São Paulo: USP, 2006. CD ROM

DA MATTA, F. M. et al. Actual and potential photosynthetic rates of tropical crop species. R. Bras.

Fisiol. Veg., v. 13, n. 1, p. 24-32, 2001

FLECK, N. G. et al. Competitividade relativa entre cultivares de arroz irrigado e biótipos de arroz-vermelho.

Planta Daninha, v. 2, n. 1, p. 101-111, 2008

FLOSS, E. L. Fisiologia das plantas cultivadas. Passo Fundo: UPF, 2008. $733 \mathrm{p}$

GALON, L. et al. Estimativa das perdas de produtividade de grãos em cultivares de arroz (Oryza sativa) pela interferência do capim-arroz (Echinochloaspp). Planta Daninha, v. 25, n. 4, p. 697-707, 2007.

HARLAN J. R.; WET, J. M. J.; PRICE, G. E. Comparative evolution of cereals. Evolution, v. 27, n. 2.p. 311-325, 1973

HUTMACHER, R. B.; KRIEG, D. R. Photosynthetic rate control in cotton. Plant Physiol., v. 73, n. 3, p. 658-661, 1983.

KIRSCHBAUM, M. U. F.; PEARCY, R. W. Gas exchange analysis of the relative importance of stomatal and biochemical factors in phosynthetic induction in

Alocasiamacrorrhiza. Plant Physiol., v. 86, n. 3, p. 782-785, 1988.

LORETO, F.; BONGI, G. Combined low temperature-high light effects on gas exchange properties of jojoba leaves. Plant Physiol., v. 91, n. 4, p.1580-1585, 1989.

MELO, P. T. B. S. et al. Comportamento de populações de arroz irrigado em função das proporções de plantas originadas de sementes de alta e baixa qualidade fisiológica. R. Bras. Agroci., v. 12, n. 1, p. 37-43, 2006.

MESSINGER, J. et al. Field assessments of gene flow from transgenic to cultivated rice (Oryza sativa L.) using a herbicide resistance gene as tracer marker. Theor.Appl. Genetics, v. 103, n. 8, p. 1151-1159, 2001.

MESSINGER, S. M. et al. Evidence for involvement of photosynthetic processes in the stomatal response to $\mathrm{CO}_{2}$. Plant Physiol., v. 140, n. 2, p. 771-778, 2006. 
NAVES-BARBIERO, C. C. et al. Fluxo de seiva e condutância estomática de duas espécies lenhosas sempre-verdes no campo sujo e cerradão. R. Bras. Fisiol.Veg., v. 12, n. 2, p. 119-134, 2000.

NISHIO, J. N.; SUN, J.; VOGELMANN, T. C. Photoinhibition and the light environment within leaves. In: BAKER, N. R.; BOWYER, J. R. (Eds.). Photoinhibition of photosynthesis. Oxford:BIOS Scientific Publishers, 1994. p. $1-24$

NOLDIN, J. A. et al. Potencial de cruzamento natural entre o arroz transgênico resistente ao herbicida glufosinato de amônio e o arroz-daninho. Planta Daninha, v. 20, n. 2, p. 243-251, 2002.

OMETTO J. P. H. B. et al. Variação temporal do isótopo estável do carbono em material arbóreo em florestas da região Amazônica. In: CONGRESSO BRASILEIRO DE ECOLOGIA, 4., 2003, Fortaleza. Anais... Rio Claro: Sociedade de Ecologia do Brasil, 2003. CD ROM.

RADOSEVICH, S.; HOLT, J.; GHERSA, C. Weed ecology: implications for management. New York: Willey \& Sons, 1997. 589 p.
REAÑO, R.; PHAM, J. L. Does cross-pollination occur during seed regeneration at the Int. Rice Genebank? Inter. Rice Res. Notes, v. 23, n. 3, p. 5-6, 1998.

SHARKEY, T. D.; RASCHKE, K. Effect of light quality on stomatal opening in leaves of Xanthium strumarium L. Plant Physiol., v. 68, n. 5, p. 1170-1174, 1981

SOCIEDADE SUL-BRASILEIRA DE ARROZ IRRIGADO - SOSBAI. Arroz irrigado: recomendações técnicas da pesquisa para o Sul do Brasil. Pelotas: EmbrapaClimaTemperado, 2007. 159 p.

TAYLOR Jr., G. E.; GUNDERSON, C. A. The response of foliar gas exchange to exogenously applied ethylene. Plant Physiol., v. 82, n. 3, p. 653-657, 1986.

VANDERZEE, D.; KENNEDY, R. A. Development of photosynthetic activity following anaerobic germination in rice-mimic grass (Echinochloa crus-gallivaroryzicola). Plant Physiol., v. 73, n. 2, p. 332-339, 1983.

WELLER, J. L.; MURFET, I. C.; REID, J. B. Pea mutants with reduced sensitivity to far-red light define an important role for phytochrome A in day-length detection. Plant Physiol., v. 114, n. 4, p. 1225-1236, 1997. 